\title{
Prevalence of food allergens sensitization and food allergies in a group of allergic Honduran children
}

\author{
Victoria Alejandra Gonzales-González ${ }^{1 *}$, Adolfo Martin Díaz², Karla Fernández² and María Félix Rivera ${ }^{3}$
}

\begin{abstract}
Background: Food allergy is a public health problem that has increased in the last decade. Despite the increasing rates in children, quality data on the burden of these diseases is lacking particularly in developing countries. Honduras has no studies in pediatric patients.

Objectives: The objective of this research was to identify the most common sensitization patterns to food through epicutaneous skin testing and food allergy rates in children and their correlation with common allergic diseases in a group of patients from Hospital of Pediatrics Maria.

Methods: Cross-sectional retrospective, descriptive study in which records and database of all allergic patients in the immunology outpatient clinic from Hospital of Pediatrics Maria were reviewed between the periods of January 2015 through June 2016.

Results: A total of 365 children were analyzed, the age of participants were in the range from 1 to 18 years, with an average of 9.8 years. Sensitization to food allergens were found in 23 , and $58.3 \%$ were poly-sensitized. The most common food allergens that patients were sensitized to: milk $9.0 \%$, eggs $6.9 \%$, peanut $4.9 \%$ and pork meat $4.4 \%$. Food allergy was confirmed via oral food challenged in $9.3 \%$ of the patients. The most frequent food allergies found were: cow's milk allergy $6 \%$, hen's egg allergy $5.2 \%$ and wheat allergy $1.9 \%$.

Conclusions: Milk and egg were the most common a food allergens found in the population studied. Most of the patients were found to be poly-sensitized. The frequent food allergies confirmed via oral food challenge were cow's milk allergy, hen's egg allergy and wheat allergy.
\end{abstract}

Keywords: Sensitization, Skin prick test, Allergens, Children, Allergy

\section{Background}

Sensitization, or the presence of allergic antibody, is a pre-requisite for development of an allergic response to an allergen. Patterns of sensitization to environmental and food allergens have previously been studied in children in an effort to better understand allergy development $[1,2]$. A reaction to a food allergen can cause a wide range of clinical responses, ranging from urticaria to anaphylaxis, the most severe form of allergic reaction

\footnotetext{
*Correspondence: ggonzales.victoria@gmail.com

${ }^{1}$ Division of Epidemiology, Universidad Nacional Autonoma de Honduras,

Tegucigalpa, Francisco Morazán, Honduras

Full list of author information is available at the end of the article
}

[3]. The current standard of care is based on identification and strict avoidance of triggering foods $[4,5]$. If criteria for anaphylaxis are met, prompt administration of epinephrine is required [6].

Food allergy rates vary by age, local diet, and many other factors [7], however eight types of food account for over $90 \%$ of allergic reactions in affected individuals: milk, eggs, peanuts, tree nuts, fish, shellfish, soy, and wheat [8]. The evaluation of a child with suspected food allergy requires a detailed history and physical examination, and confirmatory tests, such as skin prick tests (SPT) and/or serum-specific IgE testing to foods $\left(\right.$ ImmunoCAP $\left.{ }^{\circledR}\right)$. In some cases, oral food challenges (OFC) may also be required [9].

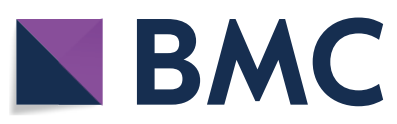

(c) The Author(s) 2018. This article is distributed under the terms of the Creative Commons Attribution 4.0 International License (http://creativecommons.org/licenses/by/4.0/), which permits unrestricted use, distribution, and reproduction in any medium, provided you give appropriate credit to the original author(s) and the source, provide a link to the Creative Commons license, and indicate if changes were made. The Creative Commons Public Domain Dedication waiver (http://creativecommons.org/ publicdomain/zero/1.0/) applies to the data made available in this article, unless otherwise stated. 
The prevalence of confirmed FA based on confirmatory tests is lower than perceived allergy, which is based on self-report. Diagnostic cut-off values for SPT have improved the diagnosis of food allergy and thereby reduced the need to perform oral food challenges [10]. However, it is a method prone to influence by a variety of factors that can add to the overall margin of error, with the potential to significantly alter test outcomes and adversely influence both the accuracy of diagnosis and the effectiveness of the subsequent immunotherapy regimens [11]. The specificity and sensitivity of skin testing is individually highly variable depending on age, body mass, and skin barrier status. In atopic inflammation skin testing gives more false positive results. Smaller skin area and strain limits prick testing in small children [12]. Other factors such as medication with antihistamines, certain antidepressants, calcineurin inhibitors or dermographism can alter the results [13].

Only one study in 50 adults have been done in Honduras by Sanchez et al. they reported a prevalence of $6 \%$ chocolate, sea food and corn, $4 \%$ for fish, peanut, beef and tomato and $2 \%$ for milk and chicken [14]. No further studies had been completed in children in this country.

The objective of this research was to identify the most common sensitizations through skin prick test and food allergy rates in children and their correlation with common allergic diseases in the group of patients from Hospital of Pediatrics Maria.

\section{Subject and methods}

Cross-sectional retrospective study in which records and database of all allergic patients in the immunology outpatient clinic from Hospital of Pediatrics Maria were reviewed between the periods of January 2015 through June 2016. 365 files were reviewed. The diagnosis of allergic diseases was established according to the GINA guidelines for asthma, ARIA for rhinitis, Hanif and Rajka for diagnoses and SCORAD for assessing the severity of atopic dermatitis [15]. Urticaria and conjunctivitis were also included. Patients meeting the criteria of two or more allergic diseases were considered as multisystemic.

We used the skin prick test method for standard procedure with commercial extracts (ALK-Abello, Madrid, Spain) for 14 food products and OFC for diagnoses of food allergy. The food panel includes: milk (cows milk allergy and casein), soy, egg yolk, egg white, peanut, beef, pork, chicken, fish, wheat, rye, oats and banana. Food panel was picked according to the common Honduran diet and according to "Programa de merienda escolar" installed by the government since 1998 .

The technique used for Skin Prick Test was the recommended according to the European standards [13].
Food allergy was diagnosed through oral food challenge at the allergy center under the supervision of a trained physician. An informed consent was obtained from each patient who recruited for OFC. Food suspected for allergy was strictly eliminated from the diet of individuals for 2 weeks prior to an OFC. Oral food and fluids were discontinued at least $12 \mathrm{~h}$ prior to OFC. During the OFC procedure, patients were monitored/supervised and regularly re-examined prior to each dose and at first signs of reaction. Total dose was divided into six incremental portions, where every next dose was double of the previous dose e.g. 1, 2, 4, 8 and $16 \mathrm{~g}$ of a solid food or 1, 2, 4, 8, $16 \mathrm{ml}$ of liquid food. In case of suspected severe reaction a much smaller dose was decided.

In cases where patients' complained of subjective symptoms (symptoms complained by the patients, i.e. throat or mouth itching, skin itching, or nausea) an observation period was allowed for the development of observable signs of an allergic reaction. However, in case no observable indications developed, OFC was continued. The results were considered "positive" until 'moderate to severe objective clinical reactions' occurred, such as respiratory, gastrointestinal, skin and cardiovascular symptoms. The challenge was stopped as soon as the observer was convinced that a reaction is occurring and medication was administered without delay.

\section{Statistical analyses}

The clinical-epidemiological information was obtained from the electronic records of the databases of the computer unit of the Hospital María, was obtained in digital format and was later transferred to Excel where an ordering and selection was made and then analyzed in epiinfo 7.2.

\section{Ethical issues}

The institutional approval of the Maria Specialty Hospital was obtained in accordance with the Declaration of Helsinki, preservation of the anonymity and privacy of research subject.

\section{Results}

A total of 365 children were analyzed in this study, ranging in age from 1 to 18 years old with an average of 9.8 years. Skin prick testing with food extracts gave a positive result in 84 children to at least one food allergen $(23 \%)$. The demographic characteristics are shown in Table 1.

Females, 48 (57.1\%) were the prevalent gender among the children that had a positive reaction to SPT. The majority of the sensitized children were in the 7-11 years old range (childhood), and 76 lived in Francisco Morazán (88.6\%). Records provided showed the most part, 62 
Table 1 Characteristics Clinical epidemiological of the children in the immunology outpatient clinic

\begin{tabular}{|c|c|c|}
\hline \multirow[t]{2}{*}{ Variable } & \multicolumn{2}{|c|}{ Sensitization to food allergen } \\
\hline & $\begin{array}{l}\text { Yes, } n=84 \\
N(\%)\end{array}$ & $\begin{array}{l}\text { No, } n=281 \\
\text { N (\%) }\end{array}$ \\
\hline \multicolumn{3}{|l|}{ Gender } \\
\hline Female & $48(57.1)$ & $122(43.4)$ \\
\hline Male & $36(42.9)$ & $159(56.6)$ \\
\hline \multicolumn{3}{|l|}{ Pediatric stage } \\
\hline Toddler (1-3 years) & $9(10.7)$ & $13(4.6)$ \\
\hline Pre-school (4-6 years) & $14(16.7)$ & $55(19.6)$ \\
\hline Childhood (7-11 years) & $33(39.3)$ & $101(35.9)$ \\
\hline Early adolescence (12-14 years) & $13(15.5)$ & $58(20.6)$ \\
\hline Late adolescence (15-18 years) & $15(17.9)$ & $54(19.2)$ \\
\hline \multicolumn{3}{|l|}{ Diagnosis } \\
\hline Multisystemic & $61(72.6)$ & $199(70.8)$ \\
\hline Allergic rhinitis & $11(13.1)$ & $38(13.5)$ \\
\hline Atopic dermatitis & $5(5.6)$ & $14(5.7)$ \\
\hline Asthma & $3(3.6)$ & $12(4.3)$ \\
\hline Urticaria & $4(4.8)$ & $6(2.1)$ \\
\hline Atopic conjunctivitis & $0(0)$ & $6(2.1)$ \\
\hline Food allergy & $34(9.3)$ & $331(90.7 \%)$ \\
\hline \multicolumn{3}{|l|}{ Procedence } \\
\hline Francisco Morazán & 76 (88.6) & $249(90.5)$ \\
\hline El Paraíso & $4(4.8)$ & $7(2.5)$ \\
\hline Intibucá & $0(0)$ & $10(3.7)$ \\
\hline Choluteca & $0(0)$ & $4(1.4)$ \\
\hline Olancho & $1(1.2)$ & $3(1.1)$ \\
\hline Comayagua & $1(1.2)$ & $2(0.7)$ \\
\hline Atlántida & $1(1.2)$ & $1(0.4)$ \\
\hline La Paz & $1(1.2)$ & $1(0.4)$ \\
\hline Copan & $0(0)$ & $1(0.4)$ \\
\hline Cortes & $0(0)$ & $1(0.4)$ \\
\hline Santa Barbara & $0(0)$ & $1(0.4)$ \\
\hline Valle & $0(0)$ & $1(0.4)$ \\
\hline
\end{tabular}

(72.6\%) had a multisystem allergic disease in which they had at least two different allergic conditions that affected two different systems.

\section{Thirty-four (9.3\%) patients were found to have food allergy and confirmed through OFC}

Table 2 details SPT results for individual food allergen test, the rates of sensitization were as follows: milk 33 (9\%), eggs $25(6.9 \%)$, peanut $18(4.9 \%)$, pork $16(4.4 \%)$, fish and soybeans $15(4.1 \%)$ each, chicken 12 (3.3\%), Oat 11 (3\%), wheat $10(1.4 \%)$, Banana $8(2.2 \%)$ and Rye $5(1.4 \%)$.

Sensitization to milk was the most frequent among food allergens. Thirty-three children had a positive SPT;
$60.6 \%$ had a reaction to cow's milks protein, while $27.3 \%$ had a positive response to casein, and $12.1 \%$ were to both allergens. Eggs were the next most common allergen, $44 \%$ had sensitization to egg whites, $28 \%$ to egg yolks and $28 \%$ to both egg whites and yolk.

Out of 365 children that visited the immunology outpatient clinic. 97.3\% did not report history of food allergy, all patients were screened through SPT to determine sensitivity and open OFC challenge was done to patients that required a diagnosis.

Food specific OFC results show that the milk is the most prevalent food allergen affecting $6 \%$ of the total patients; meanwhile and 5.2\% correspond to hen's egg allergen prevalence in the OFC trial group.

Wheat was the frequent plant food allergen with a prevalence of $1.9 \%$, as shown in Table 3. Four patients had history of anaphylaxis; written emergency actions plans were given to parents to help them recognize early signs and treatment.

Nineteen children were diagnosed with atopic dermatitis and were classified according to the SCORAD (Scoring atopic dermatitis) punctuations, as seen in Table 4. Sixteen (84.2\%) children had both, poly-sensitization and atopic dermatitis. Fourteen patients were multisystemic, or had another atopic disease as comorbidity.

Children with eczema were younger, with a median age of 7. The prevalence of poly-sensitization in this group was $84.2 \%$. Based on SCORAD score eczema was evaluated as mild in $10.5 \%$, moderate was the most frequent $52.6 \%$ followed by severe in $36.8 \%$, the mean SCORAD score is 32.6 (range of: 13-48.7).

Among 84 food-sensitized children, obesity was the most common comorbidity found in 14 (16.7\%) children followed by GERD in 9 (10.7\%), conduct disorders and acne in 6 for each $(7.1 \%)$ as seen in Table 5.

\section{Discussion}

This study determined the prevalence of food sensitization through SPT among 365 children with allergic diseases. The age of participants were in the range from 1 to 18 years, with an average of 9.8 years. The individual prevalence of food allergen sensitization type was different in our study, which may be due to cultural differences in food habits, although we cannot exclude the possibility that the lower size of our sample in comparison with other studies might have influenced the results. In spite of the fact we performed open food challenges in some of the patients, it was not possible to perform double blind placebo-controlled food challenges, which are regarded as the "gold standard" for the final diagnosis of food allergies. This was a weakness of our methodology.

Sensitization to at least one food allergen was found in $23 \%$, Similar sensitization rates had been found in 
Table 2 Prevalence of allergen sensitization in the immunology outpatient clinic

\begin{tabular}{lll}
\hline Allergen $\mathbf{n = 3 6 5}$ & Total & Positives \% \\
\hline Milk & $33 / 365$ & 9.0 \\
Egg & $25 / 365$ & 6.9 \\
Peanut & $18 / 365$ & 4.9 \\
Pork & $16 / 365$ & 4.4 \\
Fish & $15 / 365$ & 4.1 \\
Soybeans & $15 / 365$ & 4.1 \\
Chicken & $12 / 365$ & 3.3 \\
Oat & $11 / 365$ & 3.0 \\
Wheat & $10 / 365$ & 2.7 \\
Beef & $9 / 365$ & 2.3 \\
Banana & $8 / 365$ & 2.2 \\
Rye & $5 / 365$ & 1.4 \\
\hline
\end{tabular}

Table 3 Prevalence of confirmed food allergy in sensitized patients through oral food challenge

\begin{tabular}{ll}
\hline Allergen & $\begin{array}{l}\text { OFC participants, } \mathbf{n}=\mathbf{3 6 5} \\
\mathbf{N}(\%)\end{array}$ \\
\hline Animal protein & \\
Milk & $22(6.0)$ \\
Egg & $19(5.2)$ \\
Pork & $6(1.6)$ \\
Chicken & $5(1.4)$ \\
Beef & $4(1.1)$ \\
Fish & $3(0.8)$ \\
Plant food & \\
Wheat & $7(1.9)$ \\
Peanuts & $3(0.8)$ \\
Fish & $3(0.8)$ \\
Soybeans & $2(0.5)$ \\
Banana & $1(0.3)$ \\
Rye & $1(0.3)$ \\
Oat & $N D$
\end{tabular}

ND not done

similar studies in children in Germany 20\% [16] and Iran has reported higher rates $40 \%$ in previous studies [17]. Thirty-four (9.3\%) patients in this study were found to have food allergy confirmed through OFC. The types of foods most frequently implicated in our study, are included: milk, egg, peanut, wheat, and soybeans, fish.

Food allergy is an adverse immune response to a food. It is seen in $2-8 \%$ of children, mostly infants and small children, according to the data from the USA and Western Europe, the leading causes of food allergy in childhood are cow's milk proteins $(2.0-3.5 \%)$, eggs $(1.3-3.2 \%)$ peanuts $(0.6-1.3 \%)$, fish $(0.4-0.6 \%)$ and tree nuts $(0.2 \%)$ [18]. In Mexico, the Mexipreval study conducted in the year 2013-2014 reported that the highest frequency of suspected allergic reactions could be related to milk (44.5\%), fruit (25.4\%), egg (21.8\%), cereals $19.6 \%)$, seafood (13.6\%), vegetables (10.3\%), nuts $(9.2 \%)$ and fish $(8.2 \%)$ [19].

Cow's milk and eggs are one of the most important animal food allergens; therefore we evaluated the sensitization rate in this study. These patients demonstrated a 9\% sensitization to milk allergens, similar findings were reported in children in Brazil 9.1\% [20], 3.5\% China [21], and 5.6\% Australia [22]. Cow's milk allergy (CMA) was confirmed in $6 \%$ of the sensitized patients, this is a lower rate compared to a study in United States were a prevalence of $19.9 \%$ was found [23]. After CMA, hen's egg allergy is the second most common food allergy in infants and young children. Worldwide records estimate $31 \%$ egg allergy in infants [24] and $0-18 \%$ in children of all ages [25].

Animal protein sensitization to meats has been poorly described. A study in Mexican children described 13.79\% had sensitivity to pork, $8.62 \%$ to chicken and $1.72 \%$ to beef meat [26]. Data in the present work shows sensitivity prevalence of $4.4 \%$ to pork, $3.3 \%$ to chicken and $2.5 \%$ to beef; this results are similar to what has previously been described. We found no previous data that describes animal meat proteins allergy in children, however we report a $1.6 \%$ pork meat allergy, $1.4 \%$ to chicken allergy, and $1.1 \%$ to beef allergy. This may be due to tick exposure. Humans come into contacts with ticks during warmer weather, consistent with Honduran climate. Allergies that develop to these tick bites result in IgE that targets the carbohydrate alpha-gal. Alpha- gal is present in mammalian meat, and is responsible for many cases of mammalian meat allergy. In addition, that tick bites represent the

Table 4 Relationship between patients with eczema and degree of sensitization

\begin{tabular}{|c|c|c|c|}
\hline \multirow{2}{*}{$\begin{array}{l}\text { Patients with eczema } \\
\text { SCORAD }\end{array}$} & \multicolumn{3}{|l|}{ Type of sensitization } \\
\hline & Mono-sensitization, $\mathrm{n}=3 \mathrm{~N}(\%)$ & Poly-sensitization, $n=16 \mathrm{~N}(\%)$ & Total $n=19 \mathrm{~N}(\%)$ \\
\hline Mild (<20) & $0(0)$ & $2(100.0)$ & $2(10.5)$ \\
\hline Moderate (15-40) & $2(20)$ & $8(80.0)$ & $10(52.6)$ \\
\hline Severe $(>40)$ & $1(14.3)$ & $6(85.7)$ & $7(36.8)$ \\
\hline
\end{tabular}


Table 5 Comorbidities found in the food sensitized children in the outpatient clinic

\begin{tabular}{lll}
\hline Comorbidities & Total & Positives \% \\
\hline Obesity & $14 / 84$ & 16.7 \\
GERD & $9 / 84$ & 10.7 \\
Conduct disorders & $6 / 84$ & 7.1 \\
Acne & $6 / 84$ & 7.1 \\
Gastritis & $3 / 84$ & 3.6 \\
Low weight & $3 / 84$ & 3.6 \\
Thyroiditis & $3 / 84$ & 3.6 \\
Depression & $3 / 84$ & 3.6 \\
Headaches & $2 / 84$ & 2.4 \\
Arthritis & $2 / 84$ & 2.4 \\
Epilepsy & $1 / 84$ & 0.8 \\
\hline
\end{tabular}

most important cause of alpha-gal allergies by inducing specific antibodies [27].

Fish sensitization is $4.1 \%$ prevalence. Fish is a major source of dietary protein, especially in coastal areas, like Honduras. Higher sensitization for this allergen was found in Egyptian children with a prevalence of 13.8\% [10]. Fish allergy prevalence confirmed via food challenge in our study was $0.8 \%$. This is a lower rate compared to a study in the United States were sensitization rates were higher in Hispanic children for fish allergy with a prevalence of $16.2 \%$ [28]. One possibility for this difference is in spite of the country having two coasts, highly allergenic fish (salmon, swordfish, catfish and rainbow trout) are not consumed.

Wheat sensitivity via SPT was $2.7 \%$, higher rates have being described in children in Iran were a prevalence of $18.3 \%$ was found [29]. $1.9 \%$ of the sensitized children had a confirmed allergy. The prevalence of clinically relevant of wheat allergy is not well established, but it is estimated to be less than $0.5-1 \%$ with most children outgrowing it by age 16 [30].

Sensitization to peanuts was the third frequent allergen in the study group, $4.9 \%$. These data closely match with earlier reports in Latin America were 5.27-9.4\% rates were established [31-33]. The United States reports a higher prevalence, 13.04\% [34]. Peanut allergy in our study was confirmed in $0.8 \%$ of the participants, similar results were found in Canada where a prevalence of $1.5 \%$ was reported [35].

Soy protein is one major food components of the national program for scholar's meals (programa nacional de merienda escolar) in Honduras. A study in children in Chile reported a $1.3 \%$ positive SPT reaction; our study population prevalence was $4.1 \%$, similar with previous data [36]. Soy allergy is not common as cow's milk allergy in children. Data in the present work shows $0.5 \%$ suffering from soy allergy; this is in line with previous population-based studies, two European cohorts pointed rates varying up to $0.7 \%$ for children in double-blind placebo-controlled food challenge [37].

Banana, rye and oat are uncommon food allergens. Banana is one of the frequent fruits consumed by Honduran children. We found $2.2 \%$ sensitivity to banana in the study population. This result is similar to a study in Egyptian children that showed $7.5 \%$ had a positive SPT to the same allergen [38]. Eleven (3.0\%) patients visiting the outpatient clinic were sensitized to oat. The prevalence found in this study is significantly lower when compared to a study in atopic children in France where 19.2\% had a positive SPT reaction to this food allergen [39]. Rye sensitivity in this study was $1.4 \%$. Banana and oat allergy were confirmed via food challenge in our study in $0.3 \%$ of the children respectively. Patients sensitized to oat did not have oral food challenge performed.

Patients with atopic dermatitis were more likely to be poly-sensitized. Poly-sensitization and a moderate SCORAD was found in $50 \%$ of the children and coexistence between poly-sensitization and severe score was found in $31.6 \%$ of the patients. Our results are similar to a study in Netherlands that showed that children with AD faced a considerably higher risk of being sensitized to multiple allergens. Poly-sensitization was more than five times as common in children with AD than in those without [40].

A relationship between obesity and atopy has been described before, but not consistently, and food sensitization has rarely been examined in relation to obesity. This study found that 14 (16.7\%) patients that had food sensitization also had obesity. Many studies have shown that children with restrictive eating problems as FA, frequently affects quality of life, higher levels of stress and anxiety [41]; the related disorders include changes in mood, deterioration in cognitive function and in school and work performance, externalizing and oppositional behaviors [42, 43].

Food allergy remains an important health concern due to increasing prevalence worldwide, cow's milk allergy is the most prevalent, followed by hens egg allergy and wheat. Milk, egg and peanut were the frequent allergens that patients were sensitized to. This patient population had a higher rate of confirmed mammalian meat allergy compared to previous reports from North America.

\section{Abbreviations \\ FA: food allergy; SPT: skin prick test; CMA: cow's milk allergy.}

\section{Authors' contributions}

$A D, K F, V G, M R$ were responsible for the conception and design of the study. VG was responsible for acquisition of the data. VG, MR drafted the manuscript. AD, KF performed all SPT. All of the authors contributed substantially to the interpretation of the data, critically revised the manuscript for important 
intellectual content, approved the final version submitted for publication and agree to act as guarantors of the work. All authors read and approved the final manuscript.

\section{Author details}

' Division of Epidemiology, Universidad Nacional Autonoma de Honduras, Tegucigalpa, Francisco Morazán, Honduras. ${ }^{2}$ Division of Pediatric Allergy and Immunology, Hospital María de Especialidades Pediátricas, Tegucigalpa, Francisco Morazán, Honduras. ${ }^{3}$ Division of Epidemiology, Facultad de Ciencias Medicas, Universidad Nacional Autonoma de Honduras, Tegucigalpa, Francisco Morazán, Honduras.

\section{Competing interests}

The authors declare that they have no competing interests.

\section{Availability of data and materials}

All data are contained in the paper.

\section{Consent for publication}

Not applicable.

\section{Ethics approval and consent to participate}

All participants signed consent forms.

\section{Funding}

This research was investigator-initiated and received no funding.

\section{Publisher's Note}

Springer Nature remains neutral with regard to jurisdictional claims in published maps and institutional affiliations.

Received: 20 February 2017 Accepted: 28 March 2018

Published online: 18 June 2018

\section{References}

1. Prescott S, Pawankar R, Allen K, et al. A global survey of changing patterns of food allergy burden in children. Milwaukee: World Allergy Organization; 2013.

2. Makhija MM, Robinson RG, Caruso D, et al. Patterns of allergen sensitization and self reported allergic disease in parents of food allergic children. Ann Allergy Asthma Immunol. 2016;117:382-6. https://doi.org/10.1016/j. anai.2016.07.042.

3. Cianferoni A, Muraro A. Food-induced anaphylaxis. Immunol Allergy Clin North Am. 2012:32(1):165-95. https://doi.org/10.1016/j.iac.2011.10.002.

4. Xu Y, Waserman SB, Waseman S, Connors L, Stawiarski K, Kastner M. Food allergy management from the perspective of patients, caregivers, and allergist: a qualitative study. Allergy Asthma Clin Immunol. 2010;6(30):1-5. https://doi.org/10.1186/1710-1492-6-30.

5. Lanser BJ, Wright BL, Orgel KA, Vickery BP, Flesicher DM. Current options for the treatment of food allergy. Pediatr Clin North Am. 2015;62(6):153149. https://doi.org/10.1016/j.pcl.2015.07.015.

6. Bégin P, Winterroth LC, Dominguez T, et al. Safety and feasibility of oral immunotherapy to multiple allergens for food allergy. Allergy Asthma Clin Immunol Off J Can Soc Allergy Clin Immunol. 2014;10(1):1. https:// doi.org/10.1186/1710-1492-10-1.

7. Sampson HA, Aceves S, Bock SA, James J, et al. Food allergy: a practice parameter update. J allergy clin immunol. 2014;134(5):1016-25. https:// doi.org/10.1016/j.jaci.2014.05.013.

8. Chapman J, Bernstein L, Rufus $L$, et al. Food allergy: a practice parameter. Ann allergy asthma immunol. 2006;96:s1-68.

9. Waserman S, Watson W. Food allergy. Allergy Asthma Clin immunol. 2011;7(sup 1):s1-7. https://doi.org/10.1186/1710-1492-7-s1-s7.

10. Hossny E, Gad G, Shebab A, El-Haddad A. Peanut sensitization ingroup allergenic children. Allergy Asthma Clin Immunol. 2011;7(1):11. https:// doi.org/10.1186/1710-1492-7-11.
11. Fatteh S, Rekkerth D, Hadley J. Skin prick/puncture testing in north america a call for standards and consistency. Allergy Asthma Clin Immunol. 2014;10(1):44. https://doi.org/10.1186/1710-1492-10-44.

12. Jensen-Jarolim E, Jensen AN, Canonica GW. Debates in allergy medicine: molecular allergy diagnosis with ISAC will replace screenings by skin prick test in the future. World Allergy Org J. 2017;10(1):33. https://doi. org/10.1186/s40413-017-0162-3.

13. Heinzerling L, Mari A, Bergmann K-C, et al. The skin prick testEuropean standards. Clin Transl Allergy. 2013;3:3. https://doi. org/10.1186/2045-7022-3-3.

14. Sanchez R, Guzmeli V, Fernandez J. Rastreo de alergias en personal de una institución primaria. Rev Med Hond. 2016;84(1):s3.

15. Rojas AR. Quezada. Relación entre dermatitis atópica y alergia alimentaria. Rev Chil Pediatr. 2013:84(4):438-50.

16. Bergmann KC, Heinrich J, Niemann H. Current status of allergy prevalence in Germany. Position paper of the environmental medicine commission of the Robert Koch institute. Allergo J Int. 2016;25:6-10. https://doi. org/10.1007/s40629-016-0092-6.

17. Moghtaderi M, Farjadian S, Kashef S, Alyasin S, Afrasiabi M, Orooj M Specific lgE to common food allergens in children with atopic dermatitis. Iran J Immunol. 2012;9(1):32-8.

18. Radlovic N, Lekovic Z, Radlovic V, et al. Food allergy in children. Serb Arch Med. 2016;144(1-2):99-103.

19. Medina- Hernandez A, Huerta- Hernandez RE, Góngra- Melendez MA, Dominguez- Silva MG, et al. Perfil clinico-epidemiologico de pacientes con sospecha de alergia alimentaria en Mexico. Estudio mexipreval. Rev Alerg Mex. 2015;62:28-40.

20. Baldaçara RP, MdeF Fernandes, Baldaçara $L$, et al. Prevalence of allergen sensitization, most important allergens and factors associated with atopy in children. Sao Paulo Med J. 2013;131(5):301-8. https://doi. org/10.1590/1516-3180.2013.1315502.

21. Hu Y, Chen J, Li H. Comparison of food allergy prevalence among Chinese infants in Chongqing, 2009 versus 1999. Pediatr Int. 2010:52(5):820-4 https://doi.org/10.1111/j.1442-200x.2010.03166.x.

22. Osborne NJ, Koplin JJ, Martin PE, Gurrin LC, et al. Prevalence of challengeproven IgE-mediated food allergy using population-based sampling and predetermined challenge criteria in infants. J Allergy Clin Immunol. 2011;127(3):668-72. https://doi.org/10.1016/j.jaci.2011.01.039.

23. Warren CM, Jhaveri S, Warrier MR, Smith B, Gupta RS. The epidemiology of milk allergy in US children. Ann Allergy Asthma Immunol. 2013;110(5):370-4. https://doi.org/10.1016/j.anai.2013.02.016.

24. Palmer DJ, Metcalfe J, Makrides M, Gold MS, Quinn P, West CE, et al. Early regular egg exposure in infants with eczema: a randomized controlledtrial. J Allergy Clin Immunol. 2013;132(2):387-92. https://doi. org/10.1016/j.jaci.2013.05.002

25. Chen J, Hu Y, Allen KJ, Ho MH, Li H. The prevalence of food allergy in infants in Chongqing, China. Pediatr Allergy Immunol. 2011;22(4):356-60. https://doi.org/10.1111/j.1399-3038.2011.01139.x.

26. Zazuera- Aldapa ID, Espinoza- Escobar L. Sensibilizacion alergenica en niños con asma y rinitis alergica, del hospital general de Culiacan. Arch Salud sin. 2010:4(2):49-53.

27. Commins SP, Platts-Mills TAE. Tick bites and red meat allergy. Curr Opin Allergy Clin Immunol. 2013;13(4):354-9. https://doi.org/10.1097/ aci.0b013e3283624560.

28. Mahdavia M, Fox SR, Smith BM, James C, et al. Racial differences in food allergy phenotype and health care utilization among US children. J Allergy Clin Immunol Pract. 2017;5(2):352-7. https://doi.org/10.1016/j. jaip.2016.10.006.

29. Hosseini S, Shoormasti RS, Akramian R, et al. Skin prick test reactivity to common aero and food allergens among children with allergy. Iran J Med Sci. 2014;39(1):29-35.

30. Keet CA, Matsui EC, Dhillon G, Lenehan P, Paterakis M, Wood RA The natural history of wheat allergy. Ann Allergy Asthma Immunol. 2009;102(5):410-5. https://doi.org/10.1016/s1081-1206(10)60513-3.

31. Mopan J, Sanchez J, Chinchilla C, Cardona R. Prevalencia de sensibilización a leche y huevo en pacientes con sospecha de enfermedades mediadas por IgE. Rev Alerg Mex. 2015;62:41-7.

32. Ramirez- Sanchez JO, Salas- Diaz DA, Borges L, Bouchard M. Perfil de sensibilización a alérgenos inhalants y alimentarios en pacientes del instituto de Inmunología clínica del estado Merida- Venezuela. Avan Biomed. 2014;3:129-35. 
33. Gonzales-Diaz SN, Arias-Cruz A, Dominguez-Sansores LA, Galindo- Rodriguez $\mathrm{G}$. Sensibilización a alergénos alimentarios en pacientes del servicio de alergia del hospital universitario de la UANL, Monterrey. Med Univ. 2013;15(59):59-63.

34. Kumar R, Tsai HJ, Hong X, Liu X, Wang G, Pearson C, Ortiz K, Fu M, Pongracic JA, Bauchner $H$, Wang $X$. Race, ancestry and development of food allergen sensitization in early children. Pediatrics. 2011;128(4):e821-9. https://doi.org/10.1542/peds.2011-0691.

35. Kagan R, Lawrence J, Dufresne C, et al. Prevalence of peanut allergy in primary-school children in Montreal, Canada. Allergy Clin Immunol. 2003;112(6):1223-8. https://doi.org/10.1016/j.jaci.2003.09.026.

36. Martinez J, Mendez C, Talesnik E, Campos E, et al. Skin prick test of immediate hypersensitivity in a selected Chilean pediatric population. Rev med chile. 2005;133:195-201. https://doi.org/10.4067/ s0034-98872005000200007.

37. Kattan JD, Cocco RR, Järvinen KM. Milk and soy allergy. Pediatr Clin North Am. 2011;58(2):407-26. https://doi.org/10.1016/j.pcl.2011.02.005.

38. El-Sayed ZA, El-Ghoneimy DH, El-Shennawy D, Nasser MW. Evaluation of banana hypersensitivity among a group of atopic egyptian children: relation to parental/self reports. Allergy Asthma Immunol Res. 2013;5(3):150 4. https://doi.org/10.4168/aair.2013.5.3.150.
39. Bossault $P$, Lèauté- Labrèze $C$, Saubusse $E$, et al. Oat sensitization in children with atopic dermatitis: prevalence, risks and associated factors. Allergy. 2007;62(11):1251-6. https://doi. org/10.1111/j.1398-9995.2007.01527.x.

40. Broeks SA, Brand PL. Atopic dermatitis is associated with a fivefold increased risk of polysensitization in children. Acta Paediatr 2017;106(3):485-8. https://doi.org/10.1111/apa.13729.

41. Teufel M, Biedermann T, Rapps N, et al. Psychological burden of food allergy. World J Gastroenterol WJG. 2007;13(25):3456-65. https://doi. org/10.3748/wjg.v13.i25.3456.

42. Täljemark J, Råstam M, Lichtenstein P, Anckarsäter H, Kerekes N. The coexistence of psychiatric and gastrointestinal problems in children with restrictive eating in a nationwide Swedish twin study. J Eat Disord. 2017;5:25. https://doi.org/10.1186/s40337-017-0154-2.

43. Begen FM, Barnett J, Barber M, Payne R, Gowland MH, Lucas JS. Parents' and caregivers' experiences and behaviours when eating out with children with a food hypersensitivity. BMC Public Health. 2018;18:38. https:// doi.org/10.1186/s12889-017-4594-z.
Ready to submit your research? Choose BMC and benefit from:

- fast, convenient online submission

- thorough peer review by experienced researchers in your field

- rapid publication on acceptance

- support for research data, including large and complex data types

- gold Open Access which fosters wider collaboration and increased citations

- maximum visibility for your research: over $100 \mathrm{M}$ website views per year

At BMC, research is always in progress.

Learn more biomedcentral.com/submissions 